\title{
Radiopharmaceuticals for Molecular Imaging
}

\author{
Yun-Sang Lee ${ }^{*}, 1,2$ \\ ${ }^{I}$ Department of Nuclear Medicine, Seoul National University College of Medicine, 28 Yongon-dong, Jongno-gu, Seoul \\ 110-744, Korea \\ ${ }^{2}$ Institute of Radiation Medicine, Medical Research Center, Seoul National University, 28 Yongon-dong, Jongno-gu, \\ Seoul 110-744, Korea
}

\begin{abstract}
Radiopharmaceuticals for molecular imaging involve careful consideration of the following two factors: radionuclide selection and specificity to the molecular target. In selecting a radionuclide, the specific decay mode, physical half-life, chemical properties, and method of production must be considered. For proper design of a radiopharmaceutical which targets a specific biological or disease process, structural features, including the size, charge, solubility, lipophilicity, and specific activity of the radiolabeled molecules, must be considered. Other factors, such as the rate of metabolism, plasma protein binding, and non-specific binding in non-target tissues, are also important in optimizing the in vivo behavior of radiolabeled molecules. There are several types of radiopharmaceuticals for molecular imaging that target a number of biochemical processes, such as blood flow or perfusion, metabolism, and specific receptors. With a better understanding of the properties of radiopharmaceuticals, including chemical, physical, and biological properties, radiopharmaceuticals can be properly used for molecular imaging of targets for biological or disease processes.
\end{abstract}

Keywords: Radiopharmaceutical, molecular imaging, PET, SPECT.

\section{INTRODUCTION}

Molecular imaging is an emerging technology that provides images to visualize specific molecular changes in various diseases in living species $[1,2]$. Molecular imaging technology requires specific imaging modalities, such as ultrasound (US), computed tomography (CT), magnetic resonance imaging (MRI), optical imaging, and scintigraphy. Each modality has merits and shortcomings; however, only scintigraphic technology can provide high sensitivity and specificity at tracer levels and directly visualize molecular events occurring in sub-millimolar levels [3]. The main tools for scintigraphy are positron emission tomography (PET) and single photon emission computed tomography (SPECT). PET and SPECT require a radio-labeled pharmaceutical (radiopharmaceutical) or the radionuclide.

Not all, but nearly all traditional radiopharmaceuticals used in nuclear medicine imaging are also of use in molecular imaging because the concept of a 'radiotracer,' which is commonly used in nuclear medicine, is a specific radiolabeled molecule that can trace the in vivo behavior of molecules and provide information about a specific biological process. A typical example by which to visualize a biological process involves ${ }^{68} \mathrm{Ga}$-labeled Arg-Gly-Asp (RGD) peptide PET imaging, which targets angiogenesis (Fig. 1). ${ }^{68} \mathrm{Ga}-1,4,7$-triazacyclononae-1,4,7-triacitic acidRGD $\left({ }^{68}\right.$ Ga-NOTA-RGD) has a high affinity and binds firmly to $\alpha_{v} \beta_{3}$ integrin, which is highly expressed during

*Address correspondence to this author at the Department of Nuclear Medicine, Seoul National University College of Medicine, 28 YongonDong, Jongno-Gu, Seoul 110-744, Korea; Tel: +82-2-740-8906; Fax: +82-2745-7690; E-mail: wonza43@snu.ac.kr angiogenesis within the tumor vasculature [4]. Therefore, ${ }^{68} \mathrm{Ga}$-NOTA-RGD can directly visualize integrin and angiogenesis through the measurement of ${ }^{68} \mathrm{Ga}$-NOTA-RGD uptake during PET imaging. The ${ }^{68}$ Ga-NOTA-RGD application is perfectly matched with the molecular imaging concept, and other radiopharmaceuticals, which are used for functional imaging in nuclear medicine, can be used for molecular imaging.

Molecular imaging technology using radiopharmaceuticals can be used for a broad range of applications, including drug development, pharmacokinetics, clinical investigations, and routine diagnostics.

Currently, molecular imaging technology has been varied by the development of new types of radiopharmaceuticals, such as radiolabeled multimodal imaging probes [5] and oligonucleotides including nucleic acid aptamers [6, 7]. Multimodal imaging probes, which are radiolabeled MR particles containing organic dyes, can provide scintigraphic, MR and optical signals (Fig. 2). This combined technique can also provide more information and overcome the limitations of each modality. Radiolabeled oligonucleotides, for examples, radiolabeled RNA or DNA derivatives including nucleic acid aptamers, can be used for the measurement of the pharmacokinetics in vivo and evaluating the delivery of oligonucleotide derivatives to the target tissues. These newly developed radiopharmaceuticals or their technologies have been broadening the range of application of molecular imaging.

Herein we discuss important considerations for molecular imaging using radiopharmaceuticals and related applications. 


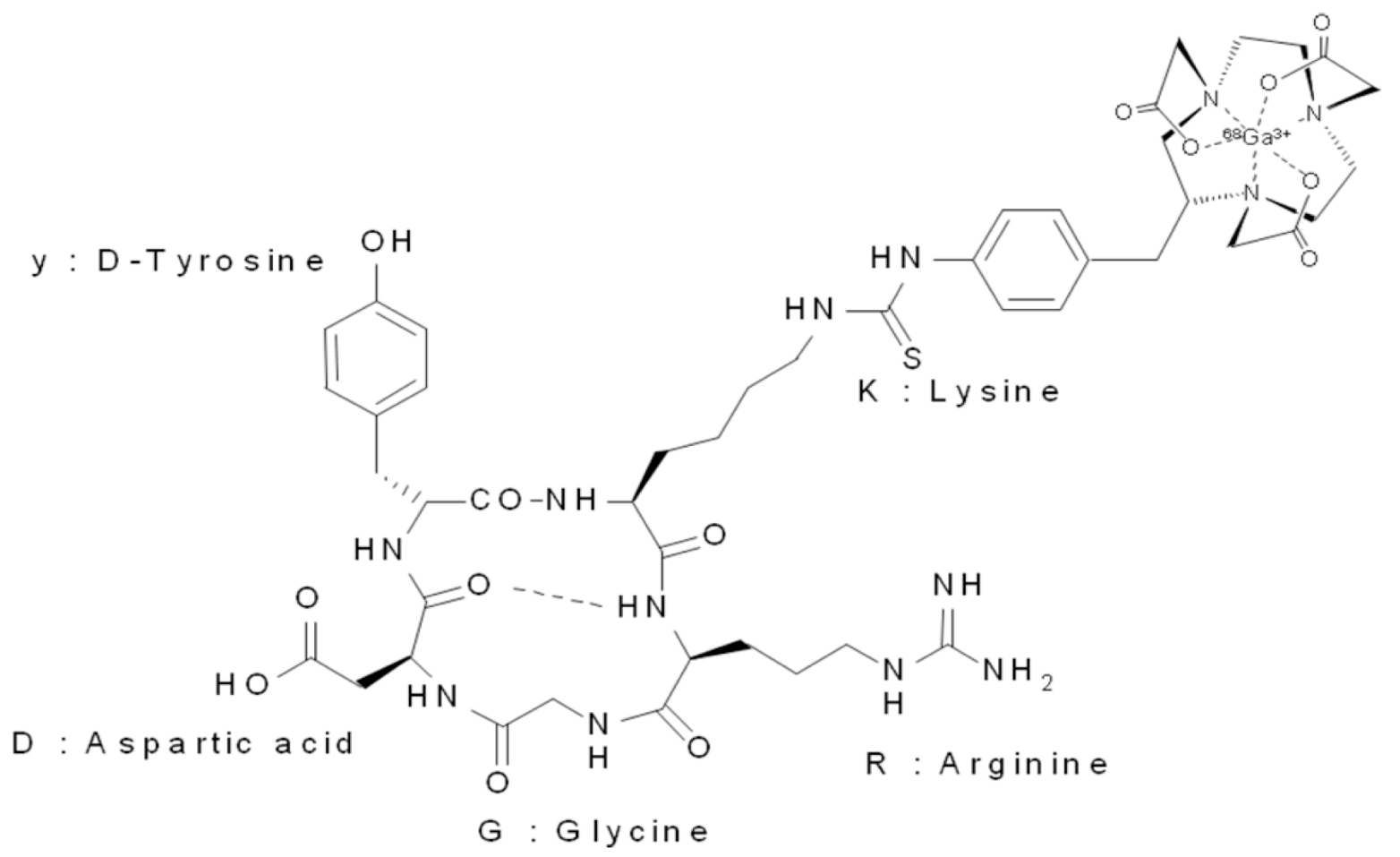

Fig. (1). The chemical structure of ${ }^{68}$ Ga-NOTA-RGD contains the Arg-Gly-Asp amino acid sequence.

\section{GENERAL CONSIDERATIONS}

To select a radiopharmaceutical or develop a new radiopharmaceutical for a specific biological target or disease, one must consider several factors. First, the choice of the radionuclide is very important because of the different time domain of each biological or disease process and the difference in each radionuclide half-life. The second factor is related to the specificity of each biological or disease target, including the size or charge of the molecule, the affinity, the specific activity, the lipophilicity, the stability, and the metabolism of the radiolabeled compounds. Moreover radiopharmaceuticals, intended for human use, should be sterile, pyrogen-free, safe, and efficacious for specific indications. Therefore, quality control procedures including physicochemical, radiochemical or biological test should be carried out for each radiopharmaceutical after synthesis.

\section{RADIONUCLIDE SELECTION}

A number of radionuclides are listed in Table 1, all of which are diagnostic radionuclides, and emit a positron or gamma photon. Each radionuclide has a specific decay mode, a physical half-life, chemical properties, and a production method. The decay mode and physical half-life is independent of any physicochemical condition, is characteristic for a given radionuclide, and cannot be changed with any other method, such as a physicochemical modification. Therefore, one must select which radionuclide is adequate for the target for the biological process or disease which is to be visualized, characterized, or measured. For example, technetium has two radioisotopes, ${ }^{94 \mathrm{~m}} \mathrm{Tc}$ and ${ }^{99 \mathrm{~m}} \mathrm{Tc}$ (Table 1). ${ }^{94 \mathrm{~m}} \mathrm{Tc}$ has a $52 \mathrm{~min}$ half-life and a positron decay mode, while ${ }^{99 \mathrm{~m}} \mathrm{Tc}$ has a $6 \mathrm{hr}$ half-life and a gamma decay mode. If the target process occurs in a period of 1 hour, one can select ${ }^{94 \mathrm{~m}} \mathrm{Tc}$ or ${ }^{99 \mathrm{~m}} \mathrm{Tc}$ to obtain the data from PET or
SPECT; however, if the target process occurs in a period of 1 day, one would have to select ${ }^{99 \mathrm{~m}} \mathrm{Tc}$ and the data could only be obtained from SPECT.

The listed radionuclides are divided into the following five groups: organic elements (C, N, and $\mathrm{O}$ ), an alkali metal $(\mathrm{Rb})$, halogens ( $\mathrm{F}$ and $\mathrm{I})$, metals ( $\mathrm{Ga}$ and $\mathrm{In})$, and transition metals $(\mathrm{Cu}$ and $\mathrm{Tc})$. The organic radionuclides are ${ }^{11} \mathrm{C},{ }^{13} \mathrm{~N}$ and ${ }^{15} \mathrm{O}$. All of these radionuclides are isotopes of natural elements, therefore radiopharmaceuticals labeled with ${ }^{11} \mathrm{C}$, ${ }^{13} \mathrm{~N}$ or ${ }^{15} \mathrm{O}$ are indistinguishable from their natural counterparts biochemically. The alkali metallic radionuclide is ${ }^{82} \mathrm{Rb}$, which has the same properties of potassium and is widely used for myocardial PET imaging [8]. The halogen radionuclides are ${ }^{18} \mathrm{~F},{ }^{123} \mathrm{I},{ }^{124} \mathrm{I}$, and ${ }^{125} \mathrm{I}$. The ${ }^{18} \mathrm{~F}$ atom closely mimics the hydrogen atom based on size, and therefore the $\mathrm{C}-{ }^{18} \mathrm{~F}$ bond shows a similar biologic behavior with the $\mathrm{C}-\mathrm{H}$ bond. There are three radioisotopes for iodine $\left({ }^{123} \mathrm{I},{ }^{124} \mathrm{I}\right.$, and $\left.{ }^{125} \mathrm{I}\right) .{ }^{123} \mathrm{I}$ emits a gamma photon, and in the last 20 years a number of radiopharmaceuticals have been developed based on ${ }^{123} \mathrm{I}$ for SPECT. ${ }^{125} \mathrm{I}$ also emits a gamma photon, but it has a 60 day physical half-life and is not affordable to humans, therefore ${ }^{125} \mathrm{I}$ is used only for in vitro and in vivo animal studies. ${ }^{124} \mathrm{I}$ is a PET version of ${ }^{123}$ I. Theoretically, all the ${ }^{123} \mathrm{I}$-labeled radiopharmaceuticals are substituted by ${ }^{124} \mathrm{I}$ labeled radiopharmaceuticals. Metallic radionuclides are ${ }^{67} \mathrm{Ga},{ }^{68} \mathrm{Ga}$, and ${ }^{111} \mathrm{In}$. Gallium is located in group 13 (IIIA) in the periodic table, likes $3^{+}$ionic form, and needs a specific chelating agent, such as 1,4,7-triazacyclononae-1,4,7-triacitic acid (NOTA; Fig. 3). ${ }^{67} \mathrm{Ga}$ and ${ }^{111}$ In emit a gamma photon and are used for SPECT. ${ }^{68} \mathrm{Ga}$ emits a positron and is used for PET. ${ }^{68} \mathrm{Ga}$ is produced by a cost-effective generator, and can be eluted 3 or 4 times per day. The transition metallic radionuclides include ${ }^{62} \mathrm{Cu},{ }^{64} \mathrm{Cu},{ }^{94 \mathrm{~m}} \mathrm{Tc}$, and ${ }^{99 \mathrm{~m}} \mathrm{Tc} .{ }^{99 \mathrm{~m}} \mathrm{Tc}$ emits a gamma photon, and ${ }^{62} \mathrm{Cu},{ }^{64} \mathrm{Cu}$, and ${ }^{94 \mathrm{~m}} \mathrm{Tc}$ emit a 


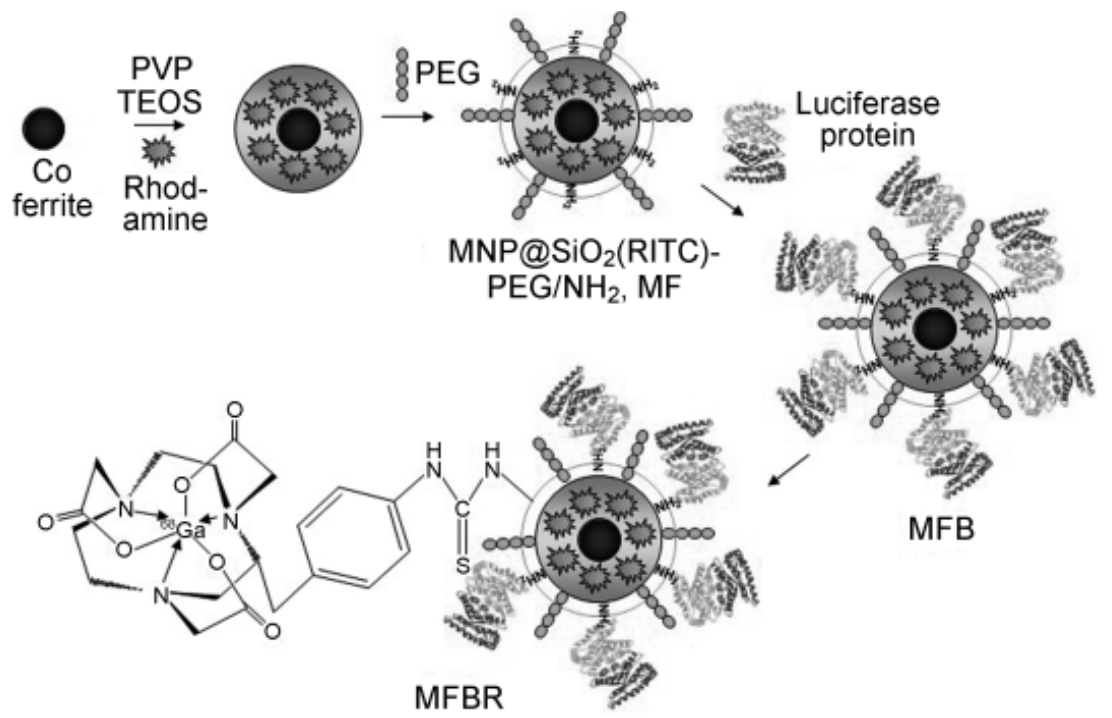

Fig. (2). Schematic diagram of the synthesis of magnetic-fluorescent-bioluminescent-radioisotopic particle (MFBR particle).

Table 1. Useful Radionuclides for Molecular Imaging

\begin{tabular}{|c|c|c|c|c|c|}
\hline Radioisotopes & Atomic Number & Physical Half-Life & Decay Mode (\%) & $\gamma$-Ray Energy (MeV) & Production \\
\hline${ }^{11} \mathrm{C}$ & 6 & $20.4 \mathrm{~min}$ & $\beta^{+}(100)$ & 0.511 & Cyclotron \\
\hline${ }^{15} \mathrm{O}$ & 8 & $2.03 \mathrm{~min}$ & $\beta^{+}(100)$ & 0.511 & Cyclotron \\
\hline${ }^{18} \mathrm{~F}$ & 9 & $109.8 \mathrm{~min}$ & $\beta^{+}(97)$ & 0.511 & Cyclotron \\
\hline${ }^{64} \mathrm{Cu}$ & 29 & $12.8 \mathrm{hr}$ & $\beta^{+}$or $\beta^{-}, \mathrm{EC}$ & 0.511 & Cyclotron \\
\hline${ }^{67} \mathrm{Ga}$ & 31 & 3.3 days & $\mathrm{EC}(100)$ & $0.093,0.184,0.300$ & Cyclotron \\
\hline${ }^{68} \mathrm{Ga}$ & 31 & $68 \mathrm{~min}$ & $\beta^{+}(89), \mathrm{EC}(11)$ & 0.511 & Generator \\
\hline${ }^{82} \mathrm{Rb}$ & 37 & $75 \mathrm{sec}$ & $\beta^{+}(95), \mathrm{EC}(5)$ & 0.511 & Generator \\
\hline${ }^{123} \mathrm{I}$ & 53 & $13.2 \mathrm{hr}$ & $\mathrm{EC}(100)$ & 0.159 & Cyclotron \\
\hline${ }^{124} \mathrm{I}$ & 53 & 4.2 days & $\beta^{+}(23), \mathrm{EC}(77)$ & 0.511 & Cyclotron \\
\hline${ }^{125} \mathrm{I}$ & 53 & 60 days & $\mathrm{EC}(100)$ & 0.035 & Reactor \\
\hline
\end{tabular}

positron. Like metallic elements, transition metals also require chelating agents. After making a complex between a metal or transition metal and a chelator, the complex has a chemical structure that affects the shape of the entire molecular structure. Therefore, metal or transition metal radiolabeling is preferred for large molecules, such as peptides, proteins, or antibodies, than small molecules. For preparation of metal- or transition metal-labeled radiopharmaceuticals, one must find the proper chelating agent for each metal or transition metal. For example, for ${ }^{68} \mathrm{Ga}$ labeling, NOTA is a better chelator than $1,4,7,10-$ tetraazacyclododecane-1,4,7,10-tetraacetic acid (DOTA; Fig. 3 ), and the ${ }^{68}$ Ga-NOTA complex is more stable than the ${ }^{68} \mathrm{Ga}$-DOTA complex. The ${ }^{68} \mathrm{Ga}$-NOTA complex is formed under room temperature; in contrast, the ${ }^{68} \mathrm{Ga}-\mathrm{DOTA}$ complex is formed under condition of heat $[9,10]$.
The method for production of radionuclides is also an important factor in radionuclide selection. The method for production of the radionuclide is related to the cost of radionuclide production and the availability of the radionuclide.

\section{THE SPECIFICITY CONCERN}

The main purpose of using radiopharmaceuticals for molecular imaging is to specifically visualize or characterize biological or disease processes at the molecular or cellular level. To maintain specificity, the radiopharmaceutical should be designed carefully for the structural requirements in a molecule in order to optimize target specificity and the pharmacokinetic and pharmacodynamic behavior of the radiopharmaceutical to meet the demands of the imaging technique. The structural features that affect the 


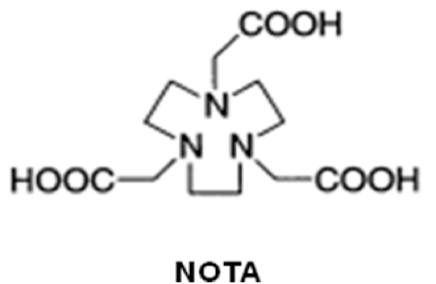

Fig. (3). Chemical structures of NOTA and DOTA.

physicochemical properties are the size, charge, solubility, lipophilicity, and specific activity (SA) of the radiolabeled molecules. Other factors, such as the rate of metabolism, plasma protein binding, and non-specific binding in nontarget tissues, are also important to optimize the in vivo behavior of radiolabeled molecules.

\section{Size and Charge}

The molecular size or mass of a radiopharmaceutical is one of the major properties of the molecule that determines the rate of clearance from the circulation and localization in vivo. Small organic molecules or small peptides, natural or synthetic, are cleared from the circulation and localized to the target tissue rapidly, thus providing a much higher targetto-background ratio. In contrast, large molecules, such as large peptides, proteins, and antibody, have a longer clearance and localization time than small molecules. The molecular size also affects the distribution pattern of radiopharmaceuticals in vivo, e.g., larger molecules are not filtered by the kidneys. Such information regarding the range of molecular weights of the desired radiopharmaceutical is essential for a given biological or disease process investigation.

The charge on a radiopharmaceutical determines its solubility in various solvents. Radiopharmaceuticals with a greater charge have a greater solubility in aqueous solution. Non-charged molecules tend to be more soluble in organic solvents and lipids. The charge of radiopharmaceuticals also determines the characteristics of the distribution pattern in vivo. For example, ${ }^{99 \mathrm{~m}} \mathrm{Tc}-$ hexakisisobutylisonitrile $\left({ }^{99 \mathrm{~m}} \mathrm{Tc}-\right.$ MIBI), which is a positively charged complex, is accumulated at the myocardium like potassium ion [11]. In contrast, ${ }^{99 \mathrm{~m}} \mathrm{Tc}$-mercaptoacetyl-Gly-Gly-Gly $\left({ }^{99 \mathrm{~m}} \mathrm{Tc}-\mathrm{MAG}_{3}\right)$, which is a negatively charged complex, is accumulated in the kidneys [12]. Several types of radiopharmaceuticals have a charge after radiolabeling, and this phenomenon occurs after the complex-forming reaction between the metal or transition metal and the chelator because of the various oxidation states of the metal or transition metal and the charge derived from the chelator molecules containing nitrogen, oxygen, or sulfur atoms. For example, a wellknown chelator for ${ }^{99 \mathrm{~m}} \mathrm{Tc}$ labeling, diaminedithiol $\left(\mathrm{N}_{2} \mathrm{~S}_{2}\right)$, can form ${ }^{99 \mathrm{~m}} \mathrm{Tc}-\mathrm{N}_{2} \mathrm{~S}_{2}$ as a neutral complex. However, dimethyl derivatives of $\mathrm{N}_{2} \mathrm{~S}_{2}$ can form a positive complex after labeling of ${ }^{99 \mathrm{~m}} \mathrm{Tc}$ [13].

\section{Solubility and Lipophilicity}

For injection in an animal model or humans, radiopharmaceuticals should be prepared in aqueous solution in the $\mathrm{pH}$ range compatible with the $\mathrm{pH}$ of blood. The ionic

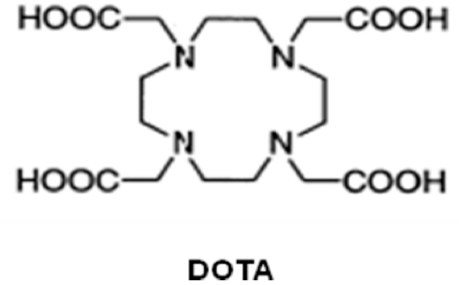

strength or osmolality of the agents should also be appropriate for blood. The solubility of radiopharmaceuticals in aqueous solution is influenced by the charge, the size, the mass, the shape, and the lipophilicity of radiopharmaceuticals.

Lipophilicity, denoted by $\log \mathrm{P}$ or $\log \mathrm{D}$, is the affinity of a molecule or moiety for a lipophilic environment, and a fundamental physicochemical property of each compound [14]. Lipophilicity also plays an important role in the absorption, distribution, and elimination of drug molecules. Normally, polar compounds exhibit high water solubility and fast clearance through the kidneys, and often highly polar compounds, such as charged compounds, cannot penetrate the blood-brain barrier (BBB). In general, only the neutral, lipophilic molecules can pass through the $\mathrm{BBB}$ and enter the brain.

\section{Specific Activity}

Generally, SA is defined as the amount of radioactivity per unit mass of an element, molecule, or compound, which implies that the mass represents the combined mass of radioactive species and the non-radioactive counterpart. The $\mathrm{SA}$ units are expressed as $\mathrm{Ci} / \mathrm{g}, \mathrm{Ci} / \mathrm{mol}$, or $\mathrm{Gbq} / \mathrm{mol}$. The $\mathrm{SA}$ of radiopharmaceuticals is very important for molecular imaging studies since $\mathrm{SA}$ is a measure of the number of radioactive probe molecules which are bound to the target system, and that can give a radioactive signal in a given mass of radiopharmaceuticals. The proper SA of a given radiopharmaceutical depends on the concentration of target molecules, such as specific receptors, enzymes, proteins or genes, present in a given cell or tissue. Normally, neuroreceptor or gene imaging studies need very high SA (2$10 \mathrm{Ci} / \mu \mathrm{mol})$, and enzyme-mediated studies need a 100-1000fold lower SA [15]. SA is related to the purity of a radiopharmaceutical and the half-life of an attached radionuclide. For example, even if we could get a highly pure radiopharmaceutical, that contains no other chemical and non-radioactive species, at the zero time point, after spending one half-life $\left(\mathrm{T}_{1 / 2}\right)$, the remaining radioactive species would be one-half of a given mass of the radiopharmaceutical. After spending 8 times the half-life, the remaining radioactive species would be only $0.4 \%$ of a given mass of the radiopharmaceutical (Fig. 4). Therefore, a low SA radiopharmaceutical, which contains a larger amount of non-radioactive species than radioactive species, is not proper for receptor or gene imaging because the number or concentration of target molecules is limited and an extremely smaller amount of radioactive species than non-radioactive species may not occupy the binding site of the target systems. To increase the SA, if possible, we should purify the radiopharmaceutical after the radiolabeling procedure or reduce the amount of precursor for radiolabeling. 


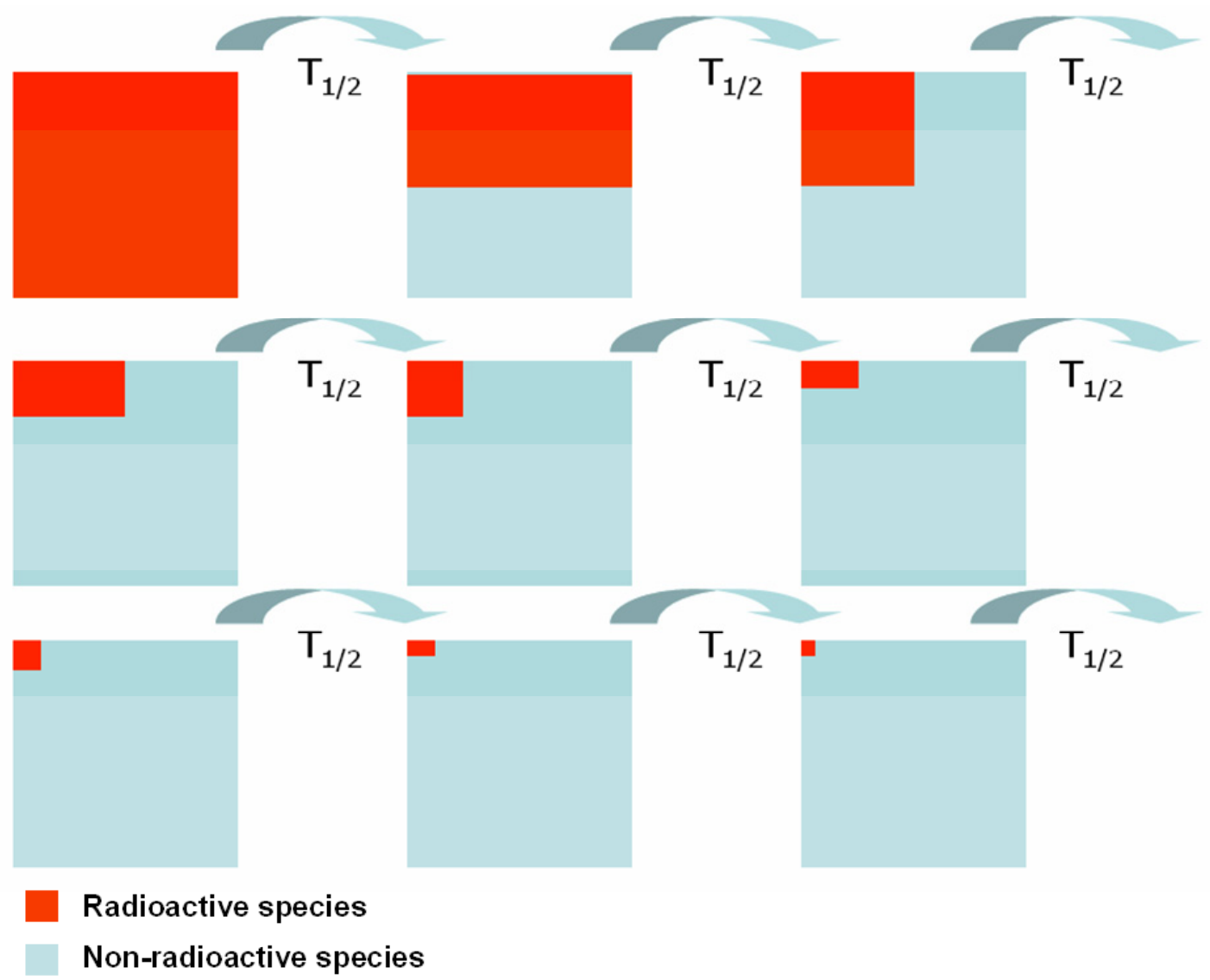

Fig. (4). SA is related to the physical half-life of the attached radionuclide.

For preparation of the radiopharmaceutical, the amount of each component to be added for the radiolabeling procedure or after purification should be known. This information is particularly important in tracer level investigations and can help better understand the image or quantification data.

\section{Stability and Metabolism}

The stability of a radiopharmaceutical is one of the major concerns in radionuclide labeling chemistry and molecular imaging. The radiopharmaceuticals for molecular imaging should be stable in vitro and in vivo. Temperature, $\mathrm{pH}$, and light affect the stability of many compounds and the optimal range of these physicochemical conditions must be established for the preparation and storage of radiolabeled compounds. In vivo, metabolically decomposed radiopharmaceuticals cause an undesirable biodistribution of radioactivity and decrease the quality of the image, which contains mixed images from the radioactivity of the intact radiolabeled molecule and metabolic fragments. Therefore, for the design of a radiopharmaceutical, radionuclide labeling should be in a metabolically stable position and an intact radiolabeled molecule should be formed a metabolically stable structure. Metabolism in the blood may decrease the delivery of the radiopharmaceutical to the target site, and at or near the target site, and may decrease the specific binding to the molecular target. Furthermore, the quantification of the molecular target concentration based of kinetic modeling may be complicated if the metabolic products are also trapped at the target site. Therefore, the relative concentration of the intact radiopharmaceutical and all the metabolic products must be measured to get a meaningful interpretation of the imaging data.

\section{Protein Binding}

It is a well-known phenomenon that almost all drugs, radioactive or not, can bind specifically or non-specifically to plasma proteins, cell membranes, and other components present in the blood to variable degrees. Protein binding is greatly influenced by a number of factors, such as the charge on the radiopharmaceutical molecule, $\mathrm{pH}$, the nature of the protein, and the concentration of anions in the plasma. Nonspecific binding to albumin and other plasma proteins is correlated positively and linearly with increasing lipophilicity [16]. Protein contains hydroxyl, carboxyl, and amino groups which determine their configuration in the protein structure and the extent and strength of protein binding to the radiopharmaceutical. Metal complexes can exchange the metal ions with proteins because of the stronger affinity of the metal for the protein. This process is called "trans-chelation" and leads to in vivo metabolism of the complex. For example, ${ }^{67}$ Ga-citrate exchanges ${ }^{67} \mathrm{Ga}$ with transferrin to form ${ }^{67} \mathrm{Ga}$-transferrin in the plasma [17].

Protein binding affects the tissue biodistribution and plasma clearance of a radiopharmaceutical and its uptake by the interest target system. Therefore, the extent of protein binding of any new radiopharmaceutical should be determined before its clinical use. 
Table 2. Frequently Used Radiopharmaceuticals for Molecular Imaging

\begin{tabular}{|c|c|c|c|c|}
\hline Blood flow & Simple diffusion & ${ }^{99 \mathrm{~m}} \mathrm{Tc}$ Red blood cell & GI bleeding, ventricle & {$[20]$} \\
\hline \multirow[t]{3}{*}{ Perfusion } & Perfusion & ${ }^{82} \mathrm{Rb},\left[{ }^{15} \mathrm{O}\right]$ Water & Myocardium, brain & {$[8,22]$} \\
\hline & & ${ }^{99 \mathrm{~m}} \mathrm{Tc}-\mathrm{MIBI},{ }^{201} \mathrm{Tl}$ & Myocardium & {$[11,23]$} \\
\hline & & ${ }^{99 \mathrm{~m}} \mathrm{Tc}-\mathrm{HMPAO}$ & Brain & {$[24]$} \\
\hline \multicolumn{5}{|l|}{ Metabolism } \\
\hline Glucose & Hexokinase & {$\left[{ }^{18} \mathrm{~F}\right] \mathrm{FDG}$} & Tumors, brain, myocardium & {$[18]$} \\
\hline Amino acids & Protein synthesis & $\begin{array}{c}{\left[{ }^{11} \mathrm{C}\right] \text { Methionine }} \\
{\left[{ }^{18} \mathrm{~F}\right] \mathrm{FMT}}\end{array}$ & Tumors & {$[27,28]$} \\
\hline Lipids & Choline kinase & $\begin{array}{l}{\left[{ }^{11} \mathrm{C}\right] \text { Choline }} \\
{\left[{ }^{18} \mathrm{~F}\right] \text { Choline }} \\
{\left[{ }^{11} \mathrm{C}\right] \text { Acetate }}\end{array}$ & Tumors & {$[31-33]$} \\
\hline Angiogenesis & $\alpha_{v} \beta_{3}$ integrin & $\begin{array}{l}{ }^{68} \mathrm{Ga}-\mathrm{NOTA}-\mathrm{RGD} \\
{\left[{ }^{18} \mathrm{~F}\right] \text { Galacto-RGD }}\end{array}$ & Tumors & {$[4,19]$} \\
\hline Hypoxia & $\begin{array}{l}\text { Acidic } \mathrm{pH} \text { and reductive } \\
\text { potential }\end{array}$ & $\begin{array}{c}{\left[{ }^{18} \mathrm{~F}\right] \mathrm{FMISO}} \\
{\left[{ }^{18} \mathrm{~F}\right] \mathrm{FAZA}} \\
{ }^{64} \mathrm{Cu}-\mathrm{ATSM}\end{array}$ & Hypoxia in tumor & [34-36] \\
\hline Apotosis & Phosphatidylserine & $\begin{array}{l}{ }^{99 \mathrm{~m}} \text { Tc-Annexin-V } \\
{\left[{ }^{124} \mathrm{I}\right] \text { Annexin-V }}\end{array}$ & Lung tumors & {$[37,38]$} \\
\hline Tumor receptors & Estrogen receptor & {$\left[{ }^{18} \mathrm{~F}\right]$ Fluoroestradiol } & Endometrial cancer & {$[39]$} \\
\hline Dopamine reuptake & $\begin{array}{l}\text { Dopamine presynaptic } \\
\text { transporter }\end{array}$ & $\begin{array}{l}{\left[{ }^{18} \mathrm{~F}\right] \mathrm{FP}-\mathrm{CIT}} \\
{\left[{ }^{123} \mathrm{I}\right]-\beta-\mathrm{CIT}}\end{array}$ & Movement disorder & {$[48,49]$} \\
\hline \multirow[t]{3}{*}{ Reporter gene imaging } & HSV1-TK & {$\left[{ }^{18} \mathrm{~F}\right] \mathrm{FHBG}$} & Gene therapy & {$[50]$} \\
\hline & Dopamine D2 receptor & {$\left[{ }^{18} \mathrm{~F}\right] \mathrm{FESP}$} & Gene therapy & {$[51]$} \\
\hline & Sodium/iodide symporter & ${ }^{123} \mathrm{I}$ & Gene therapy & {$[52]$} \\
\hline Amyliod binding & $\beta$-Amyloid & {$\left[{ }^{11} \mathrm{C}\right] \mathrm{PIB}$} & Alzheimer dementia & {$[53]$} \\
\hline Macrophage & $\begin{array}{l}\text { Peripheral benzodiazepine } \\
\text { receptor }\end{array}$ & {$\left[{ }^{11} \mathrm{C}\right] \mathrm{PK} 11195$} & Neuroinflammation & {$[56]$} \\
\hline
\end{tabular}

\section{FREQUENTLY USED RADIOPHARMACEUTICALS FOR MOLECULAR IMAGING}

There are several types of radiopharmaceuticals for molecular imaging for targeting a number of biochemical processes, such as blood flow or perfusion, metabolism, and specific receptors (Table 2). Each radiopharmaceutical focuses on specific target of each biochemical or biological process. For example, $\left[{ }^{18} \mathrm{~F}\right] \mathrm{FDG}$ can target the enzyme, hexokinase, and specifically assess the glucose metabolism in vivo [18]. In the same manner, one who wants to investigate tumor angiogenesis can focus on the specific target, such as $\alpha_{\mathrm{v}} \beta_{3}$ integrin, and can adopt ${ }^{68} \mathrm{Ga}-\mathrm{NOTA}-\mathrm{RGD}$ or $\left[{ }^{18} \mathrm{~F}\right]$ galacto-RGD to visualize angiogenesis [4, 19].

Blood flow and perfusion imaging are utilized mostly in the evaluation of heart, brain, bone, and renal applications. The radiopharmaceutical uptakes are through several different mechanisms, but the major contribution of signals derives from 
the blood flow and high first-pass extraction efficiency $[8,11$, 12, 20-26].

Metabolism imaging using radiopharmaceuticals provides important information of the hyperactivity of tissues or cells in vivo. Almost all the radiopharmaceuticals for metabolism imaging have developed with slight structural modification of natural molecules, e.g., ${ }^{11} \mathrm{C}$ - or ${ }^{18} \mathrm{~F}$-labeled radioactive analogues of carbohydrates, amino acids, nucleotides, and lipids [18, 2733].

Angiogenesis is an important process on which tumors depend to maintain growth and is subjected to regulation by growth factors, such as vascular epithelial growth factor (VEGF), inhibitors, and integrins. For imaging of angiogenesis, ${ }^{68} \mathrm{Ga}-\mathrm{NOTA}-\mathrm{RGD}$ and $\left[{ }^{18} \mathrm{~F}\right]$ galacto-RGD PET imaging of $\alpha_{\mathrm{v}} \beta_{3}$ integrin have been studied to exploit their binding to RGD containing components on extracellular matrix which are upregulated in the tumor vasculature [4, 19].

Tumor hypoxia is assessed by ${ }^{18} \mathrm{~F}$ labeled misonidazole ( $\left[{ }^{18} \mathrm{~F}\right]$ FMISO) PET imaging, which is useful for effective external beam radiation therapy [34]. ${ }^{18} \mathrm{~F}$-fluoroazomycin arabinoside ( $\left.\left[{ }^{18} \mathrm{~F}\right] \mathrm{FAZA}\right)$ and ${ }^{64} \mathrm{Cu}$-diacetyl-bis $\left(N^{4}\right.$-methylthiosemicarbazone; ${ }^{64} \mathrm{Cu}$-ATSM) are also used for imaging of tumor hypoxia $[35,36]$. Cells undergoing programmed death, or apoptosis, externalize important subcellular components, including phospohphatidylserine (PS) as potential markers of apoptosis. Naturally-occurring annexin $\mathrm{V}$ is known to be bound to exposed PS. ${ }^{99 \mathrm{~m}} \mathrm{Tc}$ or ${ }^{124} \mathrm{I}$ labeled annexin V were studied for imaging of apoptosis [37, 38].

Tumor-related specific receptor, such as estrogen and somatostatin receptor (ER and SSTR), can be imaged by ${ }^{18} \mathrm{~F}$ labeled estradiol and radiolabeled octreotide derivatives [39-42]. ${ }^{68} \mathrm{Ga}$-DOTA-Tyr ${ }^{3}$-octreotide $\left({ }^{68} \mathrm{Ga}\right.$-DOTA-TOC) is used for direct imaging of SSTR, and evaluates the therapeutic effect of the peptide receptor radiotherapy (PRRT) of neuroendocrine tumors with ${ }^{90} \mathrm{Y}$ - and ${ }^{177} \mathrm{Lu}$-DOTA-Tyr ${ }^{3}-\mathrm{Thr}^{8}$-octreotide $\left({ }^{177} \mathrm{Lu}\right.$ DOTA-TATE) [43].

To explore subtypes of cholinergic, adrenergic, histaminergic, serotoninergic, dopaminergic, and benzodiazepine receptors and transporters in humans, neuroreceptor imaging studies have been flourished to study dementia, epilepsy, movement disorders, and pain pathways, and to direct central nervous system (CNS) drug development [44]. Each radiopharmaceutical has a specific target, such as neurotransmitter metabolism, receptor activity, and reuptake site activity [45-49].

Reporter gene imaging is an emerging technology based on molecular biology and can reveal the locations of gene products and the efficacy of gene therapy [50-52]. As previously mentioned, for imaging of receptor or reporter gene, radiopharmaceuticals should be maintained the high SA because of the limited number or concentration of receptors or gene products.

Accumulation of plaques and beta amyloid in the brain is a histopathologic hallmark for the diagnosis of Alzheimer's disease. The use of ${ }^{11} \mathrm{C}$ labeled Pittsburgh compound B (PIB) has enabled accurate classification of patients with versus without Alzheimer's disease and other neurodegenerative diseases [53].

A major feature of acute or chronic neuroinflammation is the activation of microglial cells. During the early 1980s, it was discovered that increased binding of PK11195 (an isoquinoline) is a hallmark of microglial activation [54]. Their binding site is the peripheral benzodiazepine receptor (PBR; the new nomenclature is translocator protein, TSPO [55]), therefore neuroinflammation is assessed by targeting of PBR using $\left[{ }^{11} \mathrm{C}\right] \mathrm{PK} 11195$ [56].

\section{CONCLUSION}

Molecular imaging using radiopharmaceuticals has provided great opportunities to explore human diseases at the levels of compartments, organs, tissues, or even genes. Radiopharmaceutical represents any radiolabeled molecule intended for human use, and should be sterile, pyrogen-free, safe for human use, and efficacious for specific indications. With a better understanding of the properties, including the chemical, physical, and biological properties of each radiopharmaceutical, these radiopharmaceuticals can be properly used for molecular imaging of targets for biological or disease processes.

\section{ACKNOWLEDGEMENTS}

This work was supported by the Converging Research Center Program through the National Research Foundation of Korea (NRF) funded by the Ministry of Education, Science and Technology (2009-0082087) and the grant of the Korea Healthcare technology R\&D Project, Ministry of Health, Welfare \& Family Affairs (A070001), Republic of Korea.

\section{REFERENCES}

[1] Chung J-K, Lee MC. Koh chang-soon nuclear medicine. $3^{\text {rd }}$ ed. Seoul: Korea Medical Science; 2008.

[2] Saha GB. Fundamentals of nuclear pharmacy. $5^{\text {th }}$ ed. New York: Springer; 2004.

[3] Wong FC, Kim EE. A review of molecular imaging studies reaching the clinical stage. Eur J Radiol 2009; 70: 205-11.

[4] Jeong JM, Hong MK, Chang YS, et al. Preparation of a promising angiogenesis PET imaging agent: ${ }^{68}$ Ga-labeled c(RGDyK)isothiocyanatobenzyl-1,4,7-triazacyclononane-1,4,7-triacetic acid and feasibility studies in mice. J Nucl Med 2008; 49: 830-6.

[5] Hwang DW, Ko HY, Kim SK, Kim D, Lee DS, Kim S. Development of a quadruple imaging modality by using nanoparticles. Chem Eur J 2009; 15: 9387-93.

[6] Tavitian B, Terrazzino S, Kuhnast B, et al. In vivo imaging of oligonucleotides with positron emission tomography. Nat Med 1998; 4: 467-71.

[7] Hicke BJ, Stephens AW, Gould T, et al. Tumor targeting by an aptamer. J Nucl Med 2006; 47: 668-78.

[8] Budinger TF, Yano Y, Hoop B. A comparison of ${ }^{82} \mathrm{Rb}^{+}$and ${ }^{13} \mathrm{NH}_{3}$ for myocardial positron scintigraphy. J Nucl Med 1975; 16: 429-31.

[9] Parker D. Tumor targeting with radiolabeled macrocycle antibody conjugates. Chem Soc Rev 1990; 19: 271-91.

[10] Jeong JM, Kim YJ, Lee Y-S, Lee DS, Chung J-K, Lee MC. Radiolabeling of NOTA and DOTA with positron emitting ${ }^{68} \mathrm{Ga}$ and investigation of in vitro properties. Nucl Med Mol Imaging 2009; 43: 330-6.

[11] Sands H, Delano ML, Gallagher BM. Uptake of hexakis(tbutylisonitrile) technetium (I) and hexakis(isopropylisonitrile) technetium (I) by neonatal rat myocytes and human erythrocytes. J Nucl Med 1986; 27: 404-8.

[12] Fritzberg AR, Kasina S, Eshima D, Johnson DL. Synthesis and biological evaluation of technetium-99m $\mathrm{MAG}_{3}$ as a hippuran replacement. J Nucl Med 1986; 27: 111-6.

[13] Jeong JM, Lee Y-S, Joo Kim Y, et al. Cationic complex: ${ }^{99 \mathrm{~m}} \mathrm{Tc}-N, N^{\prime}-$ dimethyldiaminedithiol. Nucl Med Biol 2002; 29: 711-7.

[14] Waterhouse RN. Determination of lipophilicity and its use as a predictor of blood-brain barrier penetration of molecular imaging agents. Mol Imaging Biol 2003; 5: 376-89.

[15] Vallabhajosula S. Molecular imaging: radiopharmaceuticals for PET and SPECT. New York: Springer; 2009. 
[16] Kratochwil NA, Huber W, Muller F, Kansy M, Gerber PR. Predicting plasma protein binding of drugs: a new approach. Biochem Pharmacol 2002; 64: 1355-74.

[17] Harris AW, Sephton RG. Transferrin promotion of ${ }^{67} \mathrm{Ga}$ and ${ }^{59} \mathrm{Fe}$ uptake by cultured mouse myeloma cells. Cancer Res 1977; 37: 3634-8.

[18] Reivich M, Kuhl D, Wolf A, et al. The $\left[{ }^{18} \mathrm{~F}\right]$ fluorodeoxyglucose method for the measurement of local cerebral glucose utilization in man. Circ Res 1979; 44: 127-37.

[19] Haubner R, Wester HJ, Weber WA, et al. Noninvasive imaging of alpha(v)beta3 integrin expression using ${ }^{18} \mathrm{~F}$-labeled RGD-containing glycopeptide and positron emission tomography. Cancer Res 2001; 61: 1781-5.

[20] Schmidt P, Lohrmann HP, Heimpel H. Sodium pertechnetate as a red cell label: in vitro and in vivo studies. Br J Haematol 1976; 32: 411-20.

[21] Walsh WF, Fill HR, Harper PV. Nitrogen-13-labeled ammonia for myocardial imaging. Semin Nucl Med 1977; 7: 59-66.

[22] Ackerman RH, Subramanyam R, Correia JA, Alpert NM, Taveras JM. Positron imaging of cerebral blood flow during continuous inhalation of $\mathrm{C}^{15} \mathrm{O}_{2}$. Stroke $1980 ; 11: 45-9$

[23] Wackers FJ, Schoot JB, Sokole EB, et al. Noninvasive visualization of acute myocardial infarction in man with thallium-201. Br Heart J 1975; 37: 741-4.

[24] Holmes RA, Chaplin SB, Royston KG, et al. Cerebral uptake and retention of ${ }^{99} \mathrm{Tc}^{\mathrm{m}}$-hexamethylpropyleneamine oxime $\left({ }^{99} \mathrm{Tc}^{\mathrm{m}}-\mathrm{HM}\right.$ PAO). Nucl Med Commun 1985; 6: 443-7.

[25] Nielsen SP, Moller ML, Trap-Jensen J. ${ }^{99 m}$ Tc-DTPA scintillationcamera renography: a new method for estimation of single-kidney function. J Nucl Med 1977; 18: 112-7.

[26] Enlander D, Weber PM, dos Remedios LV. Renal cortical imaging in 35 patients: superior quality with ${ }^{99 m} \mathrm{Tc}-D M S A$. J Nucl Med 1974; 15: 743-9.

[27] Comar D, Cartron J, Maziere M, Marazano C. Labelling and metabolism of methionine-methyl- ${ }^{11}$ C. Eur J Nucl Med 1976; 1: 11-4.

[28] VanBrocklin HF, Blagoev M, Hoepping A, et al. A new precursor for the preparation of $6-\left[{ }^{18} \mathrm{~F}\right]$ Fluoro-L-m-tyrosine ( $\left.\left[{ }^{18} \mathrm{~F}\right] \mathrm{FMT}\right)$ : efficient synthesis and comparison of radiolabeling. Appl Radiat Isot 2004; 61: 1289-94.

[29] Sundoro-Wu BM, Schmall B, Conti PS, Dahl JR, Drumm P, Jacobsen JK. Selective alkylation of pyrimidyldianions: synthesis and purification of ${ }^{11} \mathrm{C}$ labeled thymidine for tumor visualization using positron emission tomography. Int J Appl Radiat Isot 1984; 35: 705-8.

[30] Been LB, Suurmeijer AJ, Cobben DC, Jager PL, Hoekstra HJ, Elsinga PH. $\left[{ }^{18}\right.$ F]FLT-PET in oncology: current status and opportunities. Eur J Nucl Med Mol Imaging 2004; 31: 1659-72.

[31] Rosen MA, Jones RM, Yano Y, Budinger TF. Carbon-11 choline: synthesis, purification, and brain uptake inhibition by 2dimethylaminoethanol. J Nucl Med 1985; 26: 1424-8.

[32] Hara T, Kondo T, Kosaka N. Use of ${ }^{18} \mathrm{~F}$-choline and ${ }^{11} \mathrm{C}$-choline as contrast agents in positron emission tomography imaging-guided stereotactic biopsy sampling of gliomas. J Neurosurg 2003; 99: 474-9.

[33] Pike VW, Eakins MN, Allan RM, Selwyn AP. Preparation of [1${ }^{11}$ Clacetate--an agent for the study of myocardial metabolism by positron emission tomography. Int J Appl Radiat Isot 1982; 33: 505-12.

[34] Jerabek PA, Patrick TB, Kilbourn MR, Dischino DD, Welch MJ. Synthesis and biodistribution of ${ }^{18} \mathrm{~F}$-labeled fluoronitroimidazoles: potential in vivo markers of hypoxic tissue. Int J Rad Appl Instrum A 1986; 37: 599-605.

[35] Piert M, Machulla HJ, Picchio M, et al. Hypoxia-specific tumor imaging with ${ }^{18} \mathrm{~F}$-fluoroazomycin arabinoside. J Nucl Med 2005; 46: 106-13.

[36] Lewis JS, McCarthy DW, McCarthy TJ, Fujibayashi Y, Welch MJ. Evaluation of ${ }^{64} \mathrm{Cu}$-ATSM in vitro and in vivo in a hypoxic tumor model. J Nucl Med 1999; 40: 177-83.

[37] Blankenberg FG, Katsikis PD, Tait JF, et al. Imaging of apoptosis (programmed cell death) with ${ }^{99 m} \mathrm{Tc}$ annexin V. J Nucl Med 1999; 40: 184-91.
[38] Glaser M, Collingridge DR, Aboagye EO, et al. Iodine-124 labelled annexin- $\mathrm{V}$ as a potential radiotracer to study apoptosis using positron emission tomography. Appl Radiat Isot 2003; 58: 55-62.

[39] Brodack JW, Kilbourn MR, Welch MJ, Katzenellenbogen JA. NCA 16 alpha- $\left[{ }^{18} \mathrm{~F}\right]$ fluoroestradiol-17 beta: the effect of reaction vessel on fluorine-18 resolubilization, product yield, and effective specific activity. Int J Rad Appl Instrum A 1986; 37: 217-21.

[40] Henze M, Schuhmacher J, Hipp P, et al. PET imaging of somatostatin receptors using ${ }^{68} \mathrm{Ga}$ DOTA-D-Phe ${ }^{1}-\mathrm{Tyr}^{3}$-octreotide: first results in patients with meningiomas. J Nucl Med 2001; 42: 1053-6.

[41] Krenning EP, Kwekkeboom DJ, Oei HY, et al. Somatostatin receptor imaging of endocrine gastrointestinal tumors. Schweiz Med Wochenschr 1992; 122: 634-7.

[42] Cwikla JB, Mikolajczak R, Pawlak D, et al. Initial direct comparison of ${ }^{99 \mathrm{~m}} \mathrm{Tc}-\mathrm{TOC}$ and ${ }^{99 \mathrm{~m}} \mathrm{Tc}$-TATE in identifying sites of disease in patients with proven GEP NETs. J Nucl Med 2008; 49: 1060-5.

[43] Li S, Beheshti M. The radionuclide molecular imaging and therapy of neuroendocrine tumors. Curr Cancer Drug Targets 2005; 5: 139-48.

[44] Lee CM, Farde L. Using positron emission tomography to facilitate CNS drug development. Trends Pharmacol Sci 2006; 27: 310-6.

[45] Eidelberg D, Moeller JR, Dhawan V, et al. The metabolic anatomy of Parkinson's disease: complementary $\left[{ }^{18} \mathrm{~F}\right]$ fluorodeoxyglucose and $\left[{ }^{18} \mathrm{~F}\right]$ fluorodopa positron emission tomographic studies. Mov Disord 1990; 5: 203-13.

[46] Ehrin E, Farde L, de Paulis T, et al. Preparation of ${ }^{11} \mathrm{C}$-labelled Raclopride, a new potent dopamine receptor antagonist: preliminary PET studies of cerebral dopamine receptors in the monkey. Int J Appl Radiat Isot 1985; 36: 269-73.

[47] Kostyniak PJ, Brenner JS, Maccubbin AE, Nakeeb S, Kasliwal R, Kung HF. The toxicity and mutagenicity of S-3-iodo-N-(1-ethyl-2pyrrolidinyl)methyl-2-hydroxy-6-methoxybenzamide (IBZM), a new CNS D-2 dopamine receptor imaging agent. Drug Chem Toxicol 1988; 11: 433-42.

[48] Neumeyer JL, Wang S, Gao Y, et al. N-omega-fluoroalkyl analogs of (1R)-2 beta-carbomethoxy-3 beta-(4-iodophenyl)-tropane (beta-CIT): radiotracers for positron emission tomography and single photon emission computed tomography imaging of dopamine transporters. J Med Chem 1994; 37: 1558-61.

[49] Innis R, Baldwin R, Sybirska E, et al. Single photon emission computed tomography imaging of monoamine reuptake sites in primate brain with $\left[{ }^{123}\right.$ I]CIT. Eur J Pharmacol 1991; 200: 369-70.

[50] Alauddin MM, Conti PS. Synthesis and preliminary evaluation of 9-(4$\left[{ }^{18} \mathrm{~F}\right]$-fluoro-3-hydroxymethylbutyl)guanine $\left.\left({ }^{18} \mathrm{~F}\right] \mathrm{FHBG}\right): \quad$ a new potential imaging agent for viral infection and gene therapy using PET. Nucl Med Biol 1998; 25: 175-80.

[51] Gambhir SS, Barrio JR, Herschman HR, Phelps ME. Assays for noninvasive imaging of reporter gene expression. Nucl Med Biol 1999; 26: 481-90

[52] Shin JH, Chung JK, Kang JH, et al. Feasibility of sodium/iodide symporter gene as a new imaging reporter gene: comparison with HSV1-tk. Eur J Nucl Med Mol Imaging 2004; 31: 425-32.

[53] Mathis CA, Wang Y, Holt DP, Huang GF, Debnath ML, Klunk WE. Synthesis and evaluation of ${ }^{11} \mathrm{C}$-labeled 6-substituted 2arylbenzothiazoles as amyloid imaging agents. J Med Chem 2003; 46: 2740-54.

[54] Weissman BA, Raveh L. Peripheral benzodiazepine receptors: on mice and human brain imaging. J Neurochem 2003; 84: 432-7.

[55] Papadopoulos V, Baraldi M, Guilarte TR, et al. Translocator protein (18kDa): new nomenclature for the peripheral-type benzodiazepine receptor based on its structure and molecular function. Trends Pharmacol Sci 2006; 27: 402-9.

[56] Gerhard A, Neumaier B, Elitok E, et al. In vivo imaging of activated microglia using $\left[{ }^{11} \mathrm{C}\right] \mathrm{PK} 11195$ and positron emission tomography in patients after ischemic stroke. Neuroreport 2000; 11: 2957-60. 